\title{
Contents, Vol. 20, 1981
}

\author{
A. Author Index 491 \\ Subject Index 493 \\ Vol.20,1981 \\ European Neurology \\ Founded 1897 as'Monatsschri \\ "t fur \\ Ps> \\ chiatrie und Neurologic',
}

continued 1957-1967 as |Psychiatria

et

Ncurologia'

Founders: C. Wernicke and Th

Zieh

en

\section{Successors: K. Bonhoeffer (191}

2-1938).

J. Klaesi (1939-1967), E. Grunthal (1953

-1967)

Editor-in-Chief:

Editorial Board:

Ad

visory Board:

H.E. Kaeser, Basel

L. Barraquer Bordas, Barcelona J.Droogleever Fortuyn, Groningen

G.G. Brunc, Munster H.P. L.udin, Bern

Associate Editors:

S. Feldman, Jerusalem

P.O. Lundberg, Uppsala

C. Loeb, Genova

P. Huber, Bern 
E. Perret. Zurich

H.-G. Mertens, Wiir/burg

A. Kreindler, Bucharest

H.B. Rieder, Basel

U.K. Rinne, Turku

H.J. I.ehmann, Essen

G. Scotto-Lavbzari, Basel

H. vander Eecken. Ghent

C. Pallis, London

P. Passouant, Montpellicr

E. Satoyoshi, Tokyo

F. Seitelberger, ViennaF. Vassella, Bern

W. Tackmann, Basel

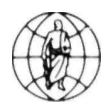

S. Karger Basel Miinchen Paris London New/York Sydney

*Iffi

All rights reserved.

No part of this publication may be translated into other languages, reproduced or utilized in any form or by any means, electronic or mechanical, including photocopying, recording, microcopying, or by any information storage and retrieval system, without permission in writing from the publisher.

S. Karger AG, P.O. Box, $\mathrm{CH}^{\wedge} \mathrm{K}$ )09 Basel (Switzerland) Printed in Switzerland by Thiir AG Offsetdruck, Pratteln

Drug Dosage

The authors and the publisher have exerted every effort to ensure that drug selection and dosage set forth in this text are in accord with current recommendations and practice at the time of publication. However, in view of ongoing research, changes in government regulations, and the constant flow of information relating to drug therapy and drug reactions, the reader is urged to check the package insert for each drug for any change in indications and dosage and for added warnings and precautions. This is particularly important when the recommended agent is a new and/or infrequently employed drug.

Contents Vol. 20,1981

No.1

Original Papers

Frontal Intermittent Rhythmic Delta Activity. A Comparative Study of EEG and CT Scan Findings

Scollo-Lavizzari, G.; Matthis, H

Acute Subdural Hematoma. Spontaneous Forms of Arterial Origin

Nizzoli, V.; Brambilla, P.; Tonnarelli, G.P 4

Circadian Variation in 5-Hydroxyindoleacetic Acid Levels in Human Cerebrospinal Fluid

Nicoletti, F.; Raffaele, R.; Falsaperle, A.; Paci, R 8

Progressive Supranuclear Palsy: Pneumoencephalography, Electronystagmography and Treatment with

Methysergide

Paulson, G.W.; Lowery, H.W.; Taylor, G.C

13

Alcoholic Epilepsy. A Definition and a Description of Other Convulsions Related to Alcoholism

Yamane, H.; Katoh, N 17

Histocompatibility Antigens in Alzheimer's Disease. A Preliminary Study

Wilcox, C.B.; Caspary, E.A.; Behan, P.0

25

Cerebral Venous Angioma, Cutaneous Angioma, Facial Asymmetry and Recurrent Stroke. A Case

Report

Tomaccini, D.; Venturi, C; Scarfo, G.B

Abnormal Serum oo-Macroglobulin in Multiple Sclerosis

Rastogi, S.C.; Clausen, J.; Fog, T

33 
Levels of Individual Serum and Cerebrospinal Fluid Proteins in Purulent and Tuberculous Meningitis

Mansour, M.M.; Guindi, S.; Girgis, N.I

Schwartz-Jampcl Syndrome: a Case Report. Stimulatory Effect of Calcium and A23187 Calcium Ionophorc for Protein Synthesis in Muscle Cultures

Scribanu, N.; Ionasescu, V 46

Salivary Secretion of Blood Group Substances in Multiple Sclerosis Patients

Wcnder, M.; Przybylski, Z.; Stawarz, M.; Chmielcwska, U

52

Myasthenia gravis: Protective Effect of Ipratropiumbromide (Atrovent ${ }^{\circledR}$ ) on Airways Obstruction Caused

by Edrophonium Chloride (Tensilon $\left.{ }^{\circledR}\right)$

Szathmary, I.; Magyar, P.; S/.obor, A 56

Pappilloedema in the Landry-Guillain-Barre-Strohl Syndrome

Bchan, P.O.; Harrington, H.; Sckoni, G

Notalgia paresthetica owing to Compression Neuropathy: Case Presentation Including Electrodiagnostic

Studies

Streib, E.W.; Sun, S.F $\quad 64$

Book Review 68

IV

Contents

No. 2

Original Papers

A Refined Method to Relate Morphological and Functional Aspects of Aphasia

Blunk, R.; De Bleser, R.; Willems, K.; Zeumer, H

69

Reversible Bilateral Internuclear Ophthalmoplegia due to Head Trauma: a Case Report

Rosati, G.; Pinna, L.; Paolino, E.; D'Agostini, G 80

A Simple Test for Topographical Diagnosis of Sensory Nervous System Lesions

Jancso, G.; Janka, Z 84

Clinical Observations on 76 Cluster Headache Cases

Manzoni, G.C.; Terzano, M.G.; Moretti, G; Cocchi, M 88

CSF Cytology of Acute Viral Meningitis and Meningoencephalitis

Pelc, S.; De Maertelaere, E.; Denolin-Reubens, R 95

Meige Syndrome: a Clinical and EMG Study

Juvarra, G.; Bettoni, L.; Lechi, A 103

The Spinal Canal in Familial Spastic Paraplegia

Vassilopoulos, D.; Spengos, M.; Zoumbou, V.; Scarpalezos, S

Pregnancy: a Factor Influencing the Course of Multiple Sclerosis?

Ghezzi, A.; Caputo, D 115

Urinary Homovanillic Acid and c-AMP in Drug-Free Parkinson Patients: Effect of L-Dopa Treatment

Markianos, M.; Hadjikonstantinou, M

Echinococcosis of the Central Nervous System

Mingde, Q.; Zhesheng, $\mathrm{H} \quad 125$

Book Reviews 132

No. 3

Deoxyglucose Uptake and Oxygen Consumption:

a Metabolic Approach to Cerebral Function

Proceedings of the International Congress CHU Saint-Antoine, Paris, September 19-20, 1980 Editors: M. Le Poncin-Lafitte and J.R. Rapin, Paris

The Deoxyglucose Method: Theory and Practice

Sokoloff, L 137

Deoxyglucose Uptake in Pathological Conditions

Rapin, J.R.; Lageron, A.; Le Poncin-Lafitte, M 146

The Deoxyglucose Method for Insects: towards Electron Microscopical Resolution

Buchner, E.; Buchner, S

152

High Resolution Radioautographic Study of the Inner Ear following in vivo Tritiated Deoxyglucose

Administration

Pumol, R.; Sans, A.; Calas, A

157

Lassen

Plate I

Fig. 1. Middle $(\mathrm{OM}+6 \mathrm{~cm})$ and upper $(\mathrm{OM}+$ 


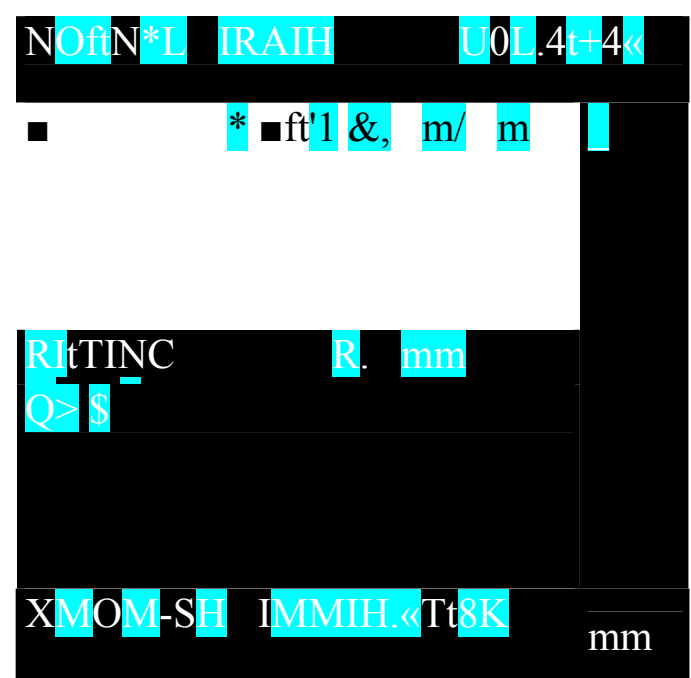

European Neurology, Vol. 20

Karger, Basel

Contents

$\mathrm{V}$

Local Cerebral Glucose Utilization in the Newborn Brain

Gregoire, N.; Pontier, R.; Salamon, G 162

Application of the 2-Deoxy-D-[14C]-Glucose Method to the Mouse for Measuring Local Cerebral Glucose Utilization

Nowaczyk, T.; Des Rosiers, M.H 169

Alterations in Local Glucose Consumption following Systemic Administration of Kainic Acid, Bicuculline or Metrazol

Ben-Ari, Y.; Riche, D.; Tremblay, E.; Charton, G

Effect of Chloral Hydrate Anaesthesia on the Cerebral Metabolic Response to Apomorphine Administration Grome, J.J.; McCulloch, J 176

Specific Behavior-Bound Brain Cartography of the Glucose Uptake Rate

Nicolaidis, S.; Le Poncin-Lafitte, M.; Danguir, J.; Grosdemouge, C; Rapin, J.R

Various Indices of Brain Metabolism and Activity in a Model of Chronic Neurological Dysfunction:

Triethyl Tin Intoxication in the Rat

Legrain, A.; MacKenzie, E.T 183

A Double Tracer Autoradiographic Technique for Simultaneous Measurement of Cerebral Blood Flow and Cerebral Metabolism in Rats

Mies, G.; Niebuhr, I.; Hossmann, K.-A

Measurements of Cerebral Oxygen Consumption: Advantages and Limitations

Siesjo, B.K 194

Determination of Tissular p02 in Brain Microvascular Research. Usefulness and Limitations

Wiernsperger, N.; Gygax, P 200

An Introduction to the Measurement of the Cerebral Oxygen Uptake Rate by Inhalation of 1502: Analysis of the Contribution of 1502 and $\mathrm{H} 2 \mathrm{lsO}$ in Brain Radioactivity

Depresseux, J.C.; Raichle, M.E.; Larson, K.B.; Markham, J.; Ter-Pogossian, M.M 207

Cerebral Oxygen Consumption in the Rat: Pharmacological Stimulation and Suppression, Role of

Catecholaminergic Mechanism

Hemmingsen, R.: Barry, D.I 215

Cerebral Oxygen Consumption and Glucose Consumption during Status epilepticus

Ingvar, M.; Siesjo, B.K 219

Inhibition of Cerebral Metabolism by Lidocaine

Astrup, J.; Sorensen, H.R 221

Continuous Estimation of Cerebral Metabolic Changes

Pinard, E.; Seylaz, J 225

Recovery from Global Cerebral Ischemia in Rabbits: Influence of Indomethacin

Boulu, R.G.; Gueniau, C; Plotkine, M.; Sofeir, M 230

Metabolic Changes Induced by Acute Hypoxia on the Synaptosomes from Dog Brain 
Benzi, G.; Arrigoni, E.; Pastoris, O.; Raimondo, S.; Fulle, D.; Curti, D.; Villa, R.F 235

Brain Enzymes and Ischemia

Villa, R.F 245

Experimental Approach of Activity and Mechanism(s) of Action of Drugs Used in Cerebral Metabolic

Insufficiency. Application to /-Eburnamonine

Linee, P.; Hollands, M.A.; Quiniou, P.; Gueguen, M.; Le Polles, J.B

Correlation of Local Blood Flow, Glucose Consumption and Probability of Necrosis following a Middle

Cerebral Artery Occlusion in the Cat

Delage, I.; Duverger, D.; Gotti, B.; MacKenzie, E.T 258

Short-Term Memory and Cerebral Ischemia: Pharmacological Application

Le Poncin-Lafitte, M.; Grosdemouge, C; Roy-Billon, C; Duterte, D.; Potrat, P.; Lespinasse, P.;

Rapin, J.R 265

VI Contents

Determination of Regional Cerebral Glucose Transport and Utilization Rates in Man with "C-Glucose:

Preliminary Results

Depresseux, J.C.; Feron, A.; Peters, J.M.; Del Fiore, G.; Quaglia, L 270

Noninvasive Tomographic Study of Cerebral Blood Flow and Oxygen Metabolism in vivo. Potentials,

Limitations, and Clinical Applications in Cerebral Ischemic Disorders

Baron, J.C.; Bousser, M.G.; Comar, D.; Soussaline, F.; Castaigne, P 273

CMRO2 and CBF by the Oxygen-15 Inhalation Technique. Results in Normal Volunteers and Cerebrovascular Patients

Lenzi, G.L.; Frackowiak, R.S.J.; Jones, T.; Heather, J.D.; Lammertsma, A.A.; Rhodes, C.G.;

Pozzilli, C 285

Regional Activation of Brain Cortex in Man Revealed by mXe Inhalation Flow Tomography (with 1

color plate)

Lassen, N.A 291

Measurements of Regional Cerebral Blood Flow and Metabolism in Psychopathological States

Ingvar, D.H 294

No. 4

Editorial

Pharmacological Principles in the Long-Term Treatment of Epilepsy

Scollo-Lavizzari, G 297

Original Papers

Immunological Findings in Epileptic and Febrile Convulsion Patients before and under Treatment

Tartara, A.; Verri, A.P.; Nespoli, L.; Moglia, A.; Botta, M.G

306

Electroencephalographic and Cranial Computed Tomographic Findings in Children with Hemiplegic

Cerebral Palsy

Ito, M.; Okuno, T.; Takao, T.; Konishi, Y.; Yoshioka, M.; Mikawa, H

Status Epilepticus with Cognitive Symptomatology in a Patient with Partial Complex Epilepsy. Case

Report

Sacquegna, T.; Pazzaglia, P.; Baldrati, A.; De Carolis, P.; Gallassi, R.; Maccheroni, M

Skew Deviation as Presenting Ocular Sign of a Third Ventricle Colloid Cyst

Kompf, D.; Szepan, B 326

Amyotrophic Lateral Sclerosis following Herpes zoster Infection in a Patient with Immunodeficiency

Maida, E.; Kristoferitsch, W 330

Neurosyphilis Today

Mapelli, G.; Pavoni, M.; Bellelli, T.; Baroncini, W.; Manente, A.; Di Bari, M

Sensory and Motor Parameters in Leg Nerves of Diabetics: Intercorrelations and Relationships to Clinical

Symptoms

Tackmann, W.; Kaeser, H.E.; Berger, W.; Riieger, A.N 344

Computerized Automated Diagnosis of Cerebellar Syndromes

Ciganek, L.; Gliviak, F.; Lesny, 1

Book Reviews 355

Announcement 356

Contents

VII

No. 5

Editorial

Neurophysiologist's and Neuropsychologist's Views on Motor Efficiency and Motor Initiation: ClinicalImplicationsPinelli, P 
Original Papers

Adrenomyeloncuropathy: Demonstration of Inclusions at the Level of the Peripheral Nerve

Julien, J.; Vallat, J.M.; Vital, C; Lagueny, A.; Ferrer, X.; Darriet, D 367

Immunoglobulin Characterization by Bacterial Absorption of Antibrain Antibodies in Multiple

Sclerosis

Ryberg, B.; Kronvall, G

374

Serological Detection of Thymoma in Myasthenia Gravis

Aarli, J.A.; Thunold, $\mathrm{S}$ 380

Neurological Sequelae in Mycosis fungoides. Report of a Case

Erp, M.G. van; Vloten, W.A. van; Groot-Verhaar, J.C. de; Buruma, O.J.S 388

Multiple Sclerosis. A Clinical Study of 70 Cases

Zhao, B.; Liu, X.; Guo, Y.; Yang, Y.; Huang, H

Fluorescein Retinal Angiography in the Early Diagnosis of Optic Disc Edema

D'Ettorre, M.; Nardini, M.; Menchini, U.; Motolese, E.; Palmeri, S.; Brancato, R.; Guazzi, G.C. . 401 Stroke Pattern and Topography of Cerebral Infarcts. A Clinicopathological Study

De Reuck, J.; Sieben, G.; De Coster, W.; Eecken, H. vander

411

Cutaneous Reflexes in the Avoidance Reaction

Dehen, H.; Wilier, J.C; Cambier, J 416

Conduction Velocity in the Human Supraorbital Nerve

Jandolo, B.; Gessini, L.; Pietrangeli, A

421

Tabetic Lightning Pains: High-Dosage Intravenous Penicillin versus Carbamazepine Therapy

Gimenez-Roldan, S.; Martin, M

424

No. 6

Original Papers

EEG Power and Coherence during Non-REM and REM Phases in Humans in All-Night Sleep

Analyses

Dumermuth, G.; Lehmann, D 429

Myasthenia gravis following Viral Infection

Lubetzki Korn, I.; Abramsky, $0 \quad 435$

An Ocular Myopathy with Glycogen Storage and Abnormal Mitochondria in Muscle Fibres.

Histochemical and Ultrastructural Findings

Scelsi, R.; Marchetti, C; Faggi, L.; Sandrini, G.; Rocchelli, B 440

Freeze-Dried Cadaveric Dural Grafts Can Stimulate a Damaging Immune Response in the Host

Johnson, M.H.; Thompson, E.J 445

Rhythmic Activity of Cat Pial Vessels in vivo

Auer, L.M.; Gallhofer, B 448

VIII

Contents

Acute Anticoagulant-Induced Compressive Lumbar Plexus Neuropathy. A Clinico-Pathological Study

Zarranz, J.J.; Simon, R.; Salisachs, P 469

Prognostic Value of the Blink Reflex in Comatose Patients

Csecsei, G.; Martini, E 473

Carpal Tunnel Syndrome in a Patient with a Cimino-Brescia Fistula

Martinelli, P.; Baruzzi, A.; Montagna, P.; Ravasio, A.; Poppi, M

Injection Injury of the Sciatic Nerve: Unusual Anatomic Distribution of Nerve Damage

Streib, E.W.; Sun, S.F

481

X-Linked Spinal and Bulbar Muscular Atrophy of Late Onset (Kennedy-Stefanis Disease?)

Papapetropoulos, T.; Panayiotopoulos, C.P

Book Reviews 489

485 